\title{
Numerical analysis of the efficiency of earth to air heat exchange systems in
} cold and hot-arid climates

\author{
Faezeh Fazlikhani a, Hossein Goudarzi a , Ebrahim Solgi ${ }^{\text {b, * }}$ \\ ${ }^{\text {a }}$ School of Architecture and Environmental Design, Iran University of Science and Technology, Tehran, Iran \\ ${ }^{\mathrm{b}}$ Department of Architecture, School of Environment, Griffith University, Australia.
}

\begin{abstract}
In order to examine and compare the efficiency of earth to air heat exchanger (EAHE) systems in hot-arid (Yazd) and cold (Hamadan) climates in Iran a steady state model was developed to evaluate the impact of various parameters including inlet air temperatures, pipe lengths and ground temperatures on the cooling and heating potential of EAHEs in both climates. The results demonstrated the ability of the system to not only improve the average temperature and decrease the temperature fluctuation of the outlet air temperature of EAHE, but also to trigger considerable energy saving. It was found that in both climates, the system is highly utilized for pre-heating, and its usage is unfeasible in certain periods throughout the year. In winter, EAHEs have the potential of increasing the air temperature in the range of $0.2-11.2^{\circ} \mathrm{C}$ and $0.1-17.2^{\circ} \mathrm{C}$ for Yazd and Hamadan, respectively. However, in summer, the system decreases the air temperature for the aforementioned cities in the range of $1.3-11.4^{\circ} \mathrm{C}$ and $5.7-11.1^{\circ} \mathrm{C}$, respectively. The system ascertains to be more efficient in the hot-arid climate of Yazd, where it can be used on 294 days of the year, leading to 50.1$63.6 \%$ energy saving, when compared to the cold climate of Hamadan, where it can be used on 225 days of the year resulting in a reduction of energy consumption by $24.5-47.9 \%$.
\end{abstract}

Keywords: Earth-air heat exchangers, Buried pipes, Hot-arid climates, Cold climates, Energy efficiency, Cooling/heating potential.

\footnotetext{
*Corresponding author:
}

Tel: +61-55527529, e-mail: ebrahim.solgi@griffithuni.edu.au 
21 . Introduction.

2. Method and material

3. Climate description

4.1. Modeling the ground temperature ....

\begin{tabular}{|c|c|}
\hline Nomenclature & Description \\
\hline$t_{a, \text { out }}$ & Outlet air temperate or temperature of air coming out of pipe $\left({ }^{\circ} \mathrm{C}\right)$. \\
\hline$t_{\text {ground }}$ & Ground temperature $\left({ }^{\circ} \mathrm{C}\right)$ \\
\hline$t_{\text {a.in }}$ & I air temperate or temperature of air entering into the pipe $\left({ }^{\circ} \mathrm{C}\right)$. \\
\hline$t_{s}$ & Average temperature of the soil surface $\left({ }^{\circ} \mathrm{C}\right)$ \\
\hline$t_{a m p}$ & Amplitude of the soil temperature $\left({ }^{\circ} \mathrm{C}\right)$ \\
\hline$m_{\text {air }}$ & Rate of air mass flow through the EAHE pipe (kg/s). \\
\hline$C_{\text {air }}$ & Air specific heat capacity at constant pressure $(\mathrm{kj} / \mathrm{kg} \mathrm{K})$. \\
\hline$L$ & Horizontal EAHE pipe length $(\mathrm{m})$ \\
\hline$R_{\text {total }}$ & Total thermal pipe resistance $\left(\mathrm{m}^{2} \circ \mathrm{C} / \mathrm{W}\right)$ \\
\hline$R_{\text {conv }}$ & Thermal convective resistance between the airflow and the inner pipe surface $\left(\mathrm{m}^{2}{ }^{\circ} \mathrm{C} / \mathrm{W}\right)$. \\
\hline$R_{\text {cond }}$ & Thermal conductive resistance of the pipe $\left(\mathrm{m}^{2} \circ \mathrm{C} / \mathrm{W}\right)$ \\
\hline$R_{\text {ground }}$ & Thermal resistance between the outer pipe surface and the ground $\left(\mathrm{m}^{2}{ }^{\circ} \mathrm{C} / \mathrm{W}\right)$. \\
\hline $\mathrm{D}_{\text {in,pipe }}$ & Inner diameter of pipe $(\mathrm{m})$ \\
\hline$D_{\text {out,pipe }}$ & Outer diameter of pipe $(\mathrm{m})$. \\
\hline $\mathrm{k}_{\text {pipe }}$ & Thermal conductivity of pipe $\left(\mathrm{W} / \mathrm{m}^{\circ} \mathrm{C}\right)$ \\
\hline $\mathrm{k}_{\text {ground }}$ & Average ground thermal conductivity $\left(\mathrm{W} / \mathrm{m}^{\circ} \mathrm{C}\right)$ \\
\hline$d_{\text {constant }}$ & Distance between the pipe surface and the undisturbed ground(m). \\
\hline$h_{c}$ & Convection coefficient of the airflow $\left(\mathrm{W} / \mathrm{m}^{2}{ }^{\circ} \mathrm{C}\right)$ \\
\hline $\mathrm{Nu}, \mathrm{Re}, \mathrm{Pr}$ & Nusselt, Reynolds and Prandtl numbers. \\
\hline$\lambda_{\text {air }}$ & Thermal conductivity of air $\left(\mathrm{W} / \mathrm{m}^{\circ} \mathrm{C}\right)$ \\
\hline$r_{i}$ & Inner radius of pipe $(\mathrm{m})$ \\
\hline$V_{a, p}$ & Air speed in the pipe $(\mathrm{m} / \mathrm{s})$ \\
\hline$v_{\text {air }}$ & Air kinematic viscosity $\left(\mathrm{m}^{2} / \mathrm{s}\right)$ \\
\hline$\mu_{\text {air }}$ & Dynamic viscosity of air $(\mathrm{kg} / \mathrm{m} \mathrm{s})$. \\
\hline$\rho_{\text {air }}$ & Air density $\left(\mathrm{kg} / \mathrm{m}^{3}\right)$ \\
\hline$C_{\text {air }}$ & Heat capacity of $\operatorname{air}\left(\mathrm{J} / \mathrm{Kg} \cdot{ }^{\circ} \mathrm{C}\right)$ \\
\hline$\rho_{\text {ground }}$ & Soil density $\left(\mathrm{kg} / \mathrm{m}^{3}\right)$ \\
\hline$C_{\text {ground }}$ & Specific heat capacity of soil $\left(\mathrm{J} / \mathrm{Kg} \cdot{ }^{\circ} \mathrm{C}\right)$ \\
\hline V & Volume of air $\left(\mathrm{m}^{3}\right)$ \\
\hline$Q$ & Cooling/Heating potential by $t_{a, o u t}(\mathrm{kWh})$. \\
\hline$z$ & the depth from the surface in meters \\
\hline$\alpha_{s}$ & Soil thermal diffusivity $\left(\mathrm{m}^{2} /\right.$ day $)$ \\
\hline$n$ & The number of target day counting from $31 \mathrm{Dec}$ \\
\hline$n_{o}$ & The number of the coldest day of the year counting from $31 \mathrm{Dec}$. \\
\hline
\end{tabular}




\section{Introduction}

In recent years, the building sector has been responsible for about $40 \%$ of the world energy consumption [1]. Buildings also contribute to more than $36 \%$ of the world total $\mathrm{CO}_{2}$ emission [2]; a share which is predicted to surge with further population growth, industrial development, and the amelioration of residential thermal comfort [3]. In developed countries, approximately 10-20\% of the total energy consumption in buildings is due to the use of HVAC systems, while this ratio reaches to about 50\% in developing countries [4]. In Iran, the building industry has been responsible for approximately $34 \%$ of the total energy consumption [5]. Additionally, the highest amount of energy demand in buildings is related to the HVAC systems with around $61 \%$ [6]. Thus, in order to reduce energy demand in buildings the need for further use of such methods as passive techniques, renewable energies and designing energy efficient buildings is growing [7]. Using ground cooling and heating is a well-known method of reducing building energy consumption and increasing thermal comfort [8] which optimizes the high thermal capacity of the soil and low-temperature fluctuations below the ground surface for cooling in summers and heating in winters [9]. This potential can be exploited through two main strategies: i) Direct Contact, in which all or some part of the building envelope is built into the ground to reduce the heat exchange with the outside [10], and ii) Indirect Contact, in which such fluids as air pass through buried pipes and exchange heat with the ground, and then pass through the building or HVAC systems to cool or heat the space and reduce the energy demand for the building [11]. The two methods are illustrated in Fig. 1.
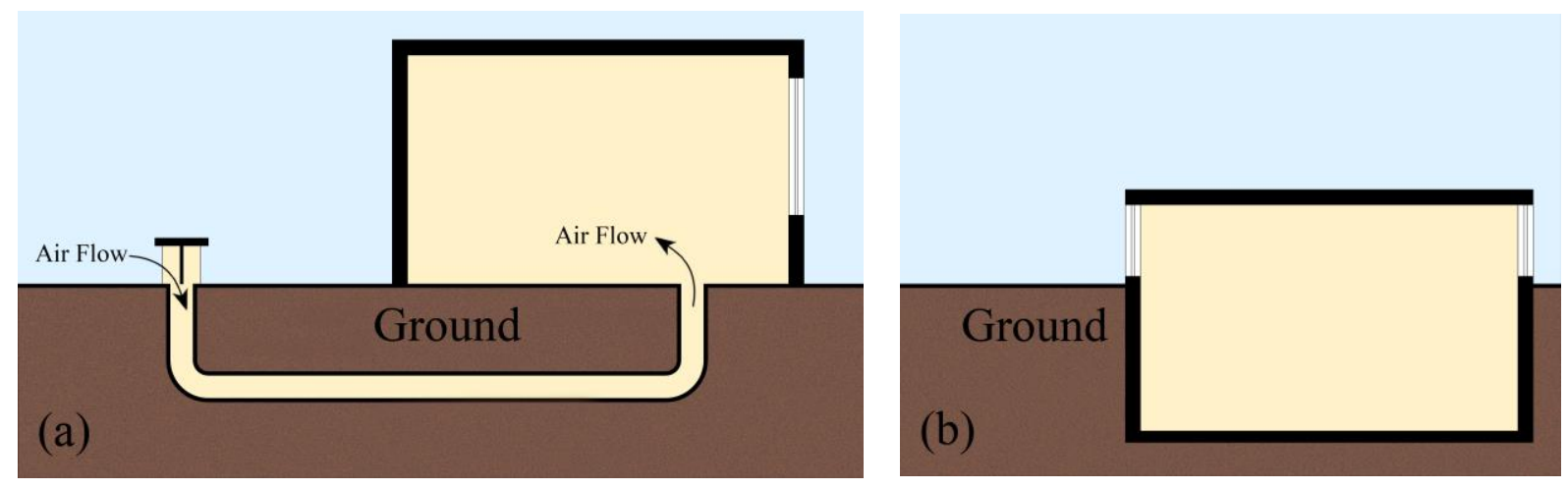

Fig. 1. Two strategies using earth temperatures, (a): Indirect contact, (b): Direct Contact

The earth to air heat exchange is a method for indirect utilization of ground temperatures for reducing the cooling/heating load [12]. In this method, energy transfer between the air and soil augments the outlet air temperature in winter and decreases it in summer [13]. The amount of heat transfer between the air and ground, and the performance of the EAHE systems depends on several factors such as the thermal properties of the soil and pipes, the air flow rate, the inlet air temperature, the pipe length, dimeter and the depth of buried pipes [14]. conditions and up to a $22^{\circ} \mathrm{C}$ reduction in the outlet air temperature of office buildings [15]. Studies 
A numerical study on an EAHE system with a pipe length of $80 \mathrm{~m}$ in Mathura in India has shown that this system can create $456 \mathrm{kWh}$ cooling potential in summer and $296 \mathrm{kWh}$ heating potential in winter and maintain the indoor air temperature at about $27.65^{\circ} \mathrm{C}[17]$. A study on the performance of EAHEs in the hot-arid climate of Kuwait has shown that the use of EAHE reduced the peak cooling load of the typical buildings by $30 \%$ in summer and cause indoor temperature reduction of $2.8{ }^{\circ} \mathrm{C}$ during peak hours [18]. Ralegaonkar et al. [19] compared EAHEs with conventional cooling systems were found that EAHEs save 90\% electricity and 100\% water in comparison with air conditioners and evaporative coolers, respectively. Mathur et al. [20] investigated EAHE performance for three different soil conditions, and concluded that higher thermal conductivity accompanies higher thermal performance. Ahmed et al. [21] examined the impact of different parameters such as pipe lengths, diameters, thicknesses, materials, depths, as well as air velocity on the thermal performance of EAHEs for the humid subtropical climate of Australia. They found that pipes with smaller diameters and thicknesses result in a higher cooling performance. It is also concluded that EAHEs with a $60 \mathrm{~m}$ pipe length and $1.5 \mathrm{~m} / \mathrm{s}$ air velocity have the maximum performance. Gallero et al. [22] developed a new simple model to evaluate thermal behavior of single U-tube ground heat exchangers and validated it against experimental data with $0.3 \%$ relative error.

18 The performance of EAHEs have been widely analyzed by numerical methods, experimental studies, and simulations using computational software. Rodrigues et al. [23] used the numerical method to find the impact of different geometrical configurations on EAHE performance. They found that an increase of duct number (complexity of geometry) leads to higher EAHE performance. Khabbaz et al. [24] conducted an experimental and numerical study on the cooling performance of EAHEs with three parallel PVC of $72 \mathrm{~m}$ length, as well as a pipe with $0.15 \mathrm{~m}$ inner diameter connected to a residential building in a hot-dry climate. Results showed that EAHEs have the potential for reducing cooling loads for one and three pipes $58 \mathrm{~W} / \mathrm{m}^{2}$ and $55 \mathrm{~W} / \mathrm{m}^{2}$, respectively. Misra et al. [25] examined EAHEs performance using Fluent software. In this research, the CFD method was used to simulate the air flow, heat transfer process, and thermal conductivity of the soil in an EAHE system. The modeled EAHE decreased the air temperature under the steady state and transient condition by approximately $18.8^{\circ} \mathrm{C}$ and $18.7-16.6^{\circ} \mathrm{C}$, respectively. Chel and Tiwari [26] studied EAHEs performance integrated with a masonry room. They employed MATLAB software to solve the heat balance equations of buildings, founding that the room air temperature during summer is lower than the ambient air temperature, although it is around $5{ }^{\circ} \mathrm{C}-15{ }^{\circ} \mathrm{C}$ higher than during winter periods. Mihalakakou et al. [27] developed a numerical model inside TRNSYS, and by virtue of that they calculated the humidity variation of the soil and air.

36 EAHEs can be utilized coupled with other passive techniques to improve their heating or cooling performance, thereby achieving a desirable efficiency. Bansal et al. [28] studied EAHEs assisted with evaporative cooling to improve the cooling potential of EAHEs. Results revealed that the evaporative cooling system enhances EAHE performance; albeit it is uneconomical. Maerefat and Haghighi [29] and Yu et al. [30] studied the integration of solar chimneys with EAHEs which resulted in improving the natural air velocity through the pipe without any need for electricity. Benhammou et al. [31] combined EAHEs with wind catchers. According to this research, the cooling potential of wind catchers coupled with EAHEs is higher than traditional wind catchers 
with wet surface. Rodrigues and Gillott [32] studied EAHEs to discharge the stored heat of phase change materials (PCMs). Results showed that the combination of PCMs with EAHEs reduces temperature fluctuations in the room by around 47\%. Jakhar et al. [33] combined a solar air heating duct and EAHEs in hot-arid climates. This research reported an increase in coefficient of performance (COP) of EAHE systems by 3.73-4.57 in winter, resulting in a $1.1-3.5^{\circ} \mathrm{C}$ rise in interior temperatures.

Due to different performance of EAHEs under various climate conditions, several research has been conducted to evaluate the cooling and heating potential of this system in different climates. Serageldin et al. [34] studied on heating and cooling potential of EAHEs in Egypt. According to the results, the increase of pipe diameter from 2 to 3 in and the air velocity from 1 to $3 \mathrm{~m} / \mathrm{s}$ decreases performance of EAHEs. Ozenger [35] investigated the heating potentival of EAHEs to find an optimal design of a greenhouse heating system for the city of Izmir in Turkey, founding that the exergy of EAHEs is $89.25 \%$ and blower and underground tunnel are major exergy destructors. Xamán et al. [36] presented EAHE performances for three cities in Mexico. The modeled EAHE provided $17.4^{\circ} \mathrm{C}$ cooling potential in Juárez (extreme weather), $10.2^{\circ} \mathrm{C}$ in Mérida (hot weather) and $10{ }^{\circ} \mathrm{C}$ in México City (mild weather), as well as $6.3{ }^{\circ} \mathrm{C}, 12.5{ }^{\circ} \mathrm{C}$ and $3.2{ }^{\circ} \mathrm{C}$ heating potential, respectively. Do et al. [37] studied the cooling energy saving of a closed-loop EAHE in the hot and humid climate of Texas in the USA, and found that EAHEs could reduce the cooling energy demand for Huston and Dallas around 9.6\% and 13.8\%, respectively. Bisoniya et al. [38] studied the heating/cooling potential of EAHEs for hot and dry climate of Bhopal in India. According to their research, using EAHEs leads to 9.6-13.8\% energy saving over a year. Abbaspour Fard et al. [39] conducted an experimental study to investigate the cooling performance of EAHEs for the semi-arid climates of Iran. The impacts of air velocity, length, diameter, depth and material of duct on the cooling performance of EAHEs were all examined. Although EAHEs have been an extensively studied research subject, literature lacks any major research into comparing their potential for cooling, heating, pre-cooling and pre-heating. The purpose of doing this research is to conduct a numerical study for EAHE performance in two different climates, hot-dry (Yazd) and cold (Hamadan) to have better an understanding the potential of EAHEs for cooling, heating proposes. However, the main contribution of this research is the examination and comparison of EAHEs performance for two different climates in Iran. The rest of this paper is organized as follows: In Section 2, the method and material is presented; Section 3 describes the geographical characteristics of Hamadan and Yazd; in Section 4, materials and methods are discussed in detail. The mathematical model is validated in Section 5, and results are presented in Section 6. Finally, a conclusion is drawn in Section 7.

\section{Method and material}

In this study, the methodology is designed based on mathematical modeling of the EAHEs in order to understand the system performance under different ambient air temperatures. For two different cities, MATLAB software is employed to develop a numerical model for the desired EAHE 
1 optimal depth for the pipes. Then the mathematical model of the EAHE system is designed. It is 2 imperative to note that the proposed EAHE in this paper is modeled as three coupled heat transfer 3 processes, namely, the convection heat transfer between the air flowing in the pipe and the inner 4 surface of the pipe, conduction heat transfer between the inner and outdoor surface of the, and the 5 conduction heat transfer between the outer surface of the pipe and soil.

6 To achieve the research objective, the hourly weather information for the two cities, gathered from 7 synoptic stations (see Table 1), is applied to obtain the exit air temperature delivered through pipe 8 outlet. Furthermore, the amount of heat transfer along the pipe between air and soil for both hot9 dry and cold climates is analyzed. In this paper, performance of modeled EAHE for cooling and 10 heating is compared and calculated. The number of days that EAHE systems can be used for 11 cooling/heating/pre-cooling/pre-heating, and the average monthly energy saving of the system are 12 presented. Fig. 2 illustrates a schematic diagram of the described stages.

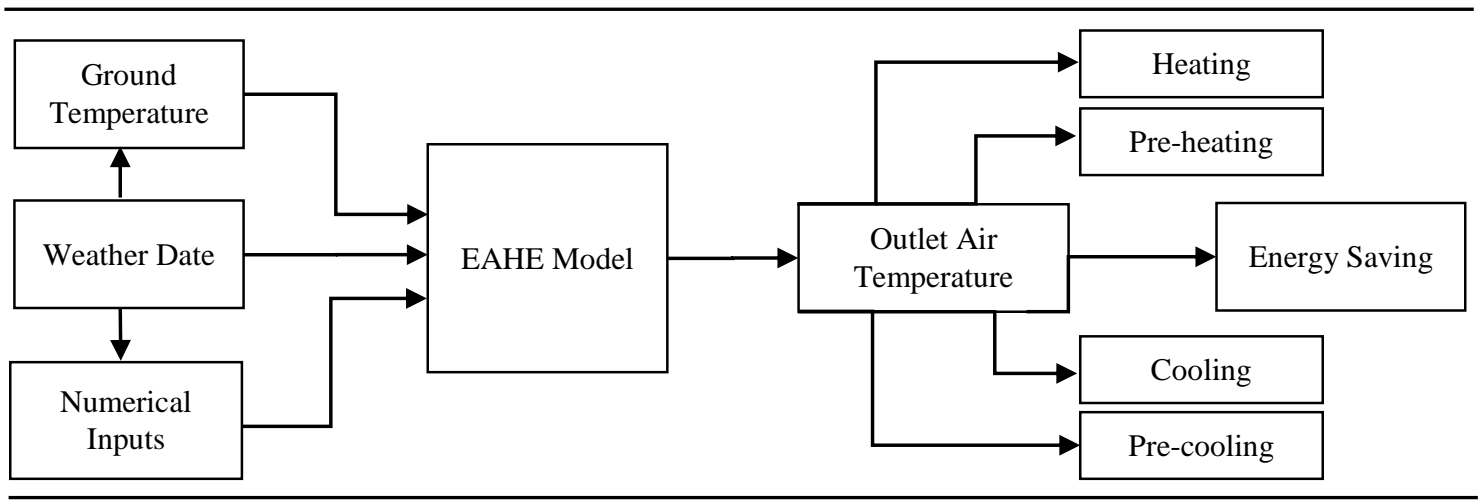

Fig. 2. Schematic Steps to the numerical evaluation of the EAHE performance in Yazd and Hamadan

\section{Climate description}

17 Yazd; located at $\left(31^{\circ} 54^{\prime} \mathrm{N}, 54^{\circ} 24^{\prime} \mathrm{E}\right)$, has a hot-arid climate with low humidity, which results in

18 high diurnal temperature fluctuations; however, Hamadan $\left(34^{\circ} 47^{\prime} \mathrm{N}, 48^{\circ} 30^{\prime} \mathrm{E}\right)$ has a cold climate 19 [40, 41]. Climatic characteristics of these cities are presented in Table 1.

Table 1

The main meteorological parameters of Yazd and Hamadan (2002-2012) [42, 43].

\begin{tabular}{|c|c|c|c|c|c|c|c|c|c|c|c|c|c|}
\hline & City & Jan & Feb & Mar & Apr & May & Jun & Jul & Aug & Sep & Oct & Nov & Dec \\
\hline \multirow{3}{*}{ 必 } & Max Temperature $\left({ }^{\circ} \mathrm{c}\right)$ & 12.8 & 17.1 & 22.8 & 27.6 & 33.5 & 38.4 & 40.5 & 38.8 & 35.0 & 29.3 & 20.2 & 14.2 \\
\hline & Average Temperature $\left({ }^{\circ} \mathrm{c}\right)$ & 6.8 & 11.2 & 15.7 & 20.7 & 26.4 & 31.1 & 33.4 & 31.2 & 27.1 & 21.6 & 13.5 & 8.0 \\
\hline & Min Temperature $\left({ }^{\circ} \mathrm{c}\right)$ & 0.8 & 4.0 & 8.6 & 13.8 & 19.3 & 23.8 & 26.2 & 23.7 & 19.2 & 14.0 & 6.9 & 1.7 \\
\hline \multirow{3}{*}{ 莣 } & Max Temperature $\left({ }^{\circ} \mathrm{C}\right)$ & 1.2 & 6.3 & 13.3 & 16.7 & 22.5 & 28.4 & 30.7 & 28.8 & 25.6 & 20.7 & 11.8 & 6 \\
\hline & Average Temperature $\left({ }^{\circ} \mathrm{c}\right)$ & -3.1 & 1.1 & 7.1 & 11.5 & 16.1 & 21.8 & 25.4 & 24.7 & 19.8 & 14.0 & 5.7 & 0.7 \\
\hline & Min Temperature $\left({ }^{\circ} \mathrm{c}\right)$ & -11.3 & -5.3 & -1.45 & 2.5 & 6.6 & 10.6 & 13.6 & 12.7 & 8.7 & 4.55 & -2.2 & -6.9 \\
\hline
\end{tabular}


2 In this research, the EAHE system has an open loop circulation, and the buried pipe is made of 3 high-density polyethylene with a conductivity of $0.50 \mathrm{~W} / \mathrm{m}^{\circ} \mathrm{C}$. The buried pipe also has a circular 4 cross-section with an inner diameter of $20 \mathrm{~cm}$ and an outer diameter of $20.5 \mathrm{~cm}$. In addition, the 5 air velocity with constant pressure inside the pipe is maintained at $2.5 \mathrm{~m} / \mathrm{s}$ by a fan. In this model, $6 \mathrm{t}_{\mathrm{a}, \mathrm{in}}$ is the inlet air temperature, which is assumed to be equal to hourly ambient air temperatures, 7 and $t_{a, \text { out }}$ is the outlet air temperature, i.e. the temperature of the exit air delivered thorough pipe 8 outlet. For both cities, the average ground thermal conductivity is $2.1 \mathrm{~W} / \mathrm{m}^{\circ} \mathrm{C}$. A general schematic 9 diagram of the developed model is shown in Fig. 3.

\subsection{Modeling the ground temperature}

The soil temperature at certain depths is one of the most important factors determining the heating and cooling efficiency of EAHE systems. An algorithm for evolution of subsurface soil temperatures is developed by Kusuda-Achenbach [44], and it has been used by Al-Ajmi et al. [18], Peretti et al. [12] and Gan [45]. Through this mathematical formula, soil temperature can be calculated with an error of less than $\pm 1^{\circ} \mathrm{C}$ [46]. It is significant to note that the soil surrounding the pipe is isotropic, with homogenous thermal conductivity at all depths. The heat conduction by soil is given by the follow equation [47]:

23

$24 \quad \frac{\partial T}{\partial t}=\alpha_{s} \frac{\partial^{2} T}{\partial z^{2}}$

25

$26 \frac{\partial^{2} T}{\partial z^{2}}-\frac{1}{\alpha_{s}} \frac{\partial T}{\partial t}=0$ 
At $z=0 \rightarrow T(0, t)=t_{\mathrm{s}}+t_{\text {amp }} \times \cos \left(\omega\left(t-t_{0}\right)\right) \quad$ and $\quad z=\infty \rightarrow T(\infty, t)=t_{\mathrm{s}}$

The solution of Eq. (2) gives the following equation to evaluate the ground temperature at a certain time and depth:

$7 \quad t_{\text {ground }}=t_{s}-t_{\text {amp }} \times \exp \left(-z \sqrt{\frac{\pi}{365 \alpha_{s}}}\right) \sin \left[\frac{2 \pi\left(n-n_{o}\right)}{365}-z \sqrt{\frac{\pi}{365 \alpha_{s}}}-\frac{\pi}{2}\right]$

Where $t_{\text {ground }}$ is the ground temperature at a certain depth and time, $t_{s}$ is the average temperature of the soil surface, $t_{a m p}$ is the amplitude of the soil temperature, and $\alpha_{s}$ is the soil thermal

$\alpha_{s}=k_{\text {ground }} /\left(C_{\text {ground }} \times \rho_{\text {ground }}\right)$

Where $C_{\text {ground }}$ is specific heat capacity, $\rho_{\text {ground }}$ is soil density and $k_{\text {ground }}$ is soil thermal conductivity. Both cities are covered with different types of soil, but the major area of land for both cities is covered with sandy-loam soil with 5-15\% humidity and $1285-2050\left(\mathrm{~kg} / \mathrm{m}^{3}\right)$ density. Furthermore, for soil with $1285\left(\mathrm{~J} / \mathrm{Kg} .{ }^{\circ} \mathrm{C}\right)$ specific heat capacity the thermal conductivity is 2.1 $\left(\mathrm{W} / \mathrm{m} .{ }^{\circ} \mathrm{C}\right)$ [48]. Thus, for both cities, the thermal diffusivity is $0.0045\left(\mathrm{~m}^{2} /\right.$ hour $)$ or $0.1\left(\mathrm{~m}^{2} /\right.$ day). The main values required to calculate the daily soil temperature at various depths are listed in Table 2. Where $t_{s}$ is the annual average of the soil temperature in $\left({ }^{\circ} \mathrm{C}\right), n$ is the number of days from 31 December, $n_{o}$ is the number of cold days from 31 December. For the city of Yazd $n_{o}$ is January $18^{\text {th }}$ with $0.8\left({ }^{\circ} \mathrm{C}\right)$, and for Hamadan is January $12^{\text {th }}$ with $-14.1\left({ }^{\circ} \mathrm{C}\right) . A_{o}$ also indicates the amplitude of soil temperature in $\left({ }^{\circ} \mathrm{C}\right)$ and is considered to be $18.0{ }^{\circ} \mathrm{C}$ for Yazd and $12.0{ }^{\circ} \mathrm{C}$ for Hamadan.

Table 2

Values for the calculation of ground temperature based on 2012 climate data.

\begin{tabular}{|c|c|c|c|c|c|c|c|c|c|c|}
\hline \multirow{2}{*}{ City } & \multirow{2}{*}{ Climate type } & \multirow{2}{*}{$n$} & \multirow{2}{*}{$n_{o}$} & $t_{a m p}$ & $t_{s}$ & $z$ & $k_{\text {ground }}$ & $\rho_{\text {ground }}$ & $C_{\text {ground }}$ & $\alpha_{s}$ \\
\hline & & & & ${ }^{\circ} \mathrm{C}$ & ${ }^{\circ} \mathrm{C}$ & $\mathrm{m}$ & $\mathrm{W} / \mathrm{m} .{ }^{\circ} \mathrm{C}$ & $\mathrm{m}^{3}$ & $\mathrm{~J} / \mathrm{Kg} \cdot{ }^{\circ} \mathrm{C}$ & $\mathrm{m}^{2} / \mathrm{day}$ \\
\hline Yazd & Hot and Dry & \multirow{2}{*}{$1-365$} & 18 & 14.0 & 18.0 & \multirow{2}{*}{$\begin{array}{c}0.2,1.0,3.0 \\
\text { and } 5.0\end{array}$} & \multirow{2}{*}{$2.1[48]$} & \multirow{2}{*}{1285} & \multirow{2}{*}{1285} & \multirow{2}{*}{0.1} \\
\hline Hamadan & Cold & & 12 & 12.2 & 12.0 & & & & & \\
\hline
\end{tabular}

\subsection{Modeling the outlet air temperature}

The air flow into the buried pipes transmitted energy into the soil that has effect on soil temperature over a year. In the present model, the undisturbed soil temperature is at a specified finite radius. And, air pressure and velocity are assumed to be constant over the length of the pipe. An algorithm to evaluate outlet air temperatures has been defined by Elmer and Schiller [49], being used by Derbel and Kanoun [47], Maerefat and Haghighi[50], Belatrache et al. [51]. The energy balance 
$2 \mathrm{dQ}=\mathrm{m}_{\mathrm{air}} \times \mathrm{C}_{\mathrm{air}} \times \frac{\mathrm{dt}_{\mathrm{a}, \mathrm{in}}}{\mathrm{d} x} \times \mathrm{d} x$

3 or

$4 \mathrm{dQ}=\left(t_{\text {ground }}-t_{\text {a.in }}\right) \times\left(\frac{1}{R_{\text {total }}}\right) \mathrm{d} x$

6 Where $R_{\text {total }}$ is the total thermal resistance of the system. Combining Eqs. (6) and (7), overall 7 energy balance for EAHEs can be expressed as follows:

$9 \mathrm{~m}_{\text {air }} \times \mathrm{C}_{\text {air }} \times \frac{\mathrm{dt}_{\mathrm{a}, \text { in }}}{\mathrm{d} x} \times \mathrm{d} x=\left(t_{\text {ground }}-t_{\text {a.in }}\right) \times\left(\frac{1}{R_{\text {total }}}\right) \mathrm{d} x$

$\frac{\mathrm{dt}_{\mathrm{ain}}}{\left(t_{\text {ground }}-t_{\text {a.in }}\right)}=\left(\frac{1}{\mathrm{~m}_{\mathrm{air}} \times \mathrm{C}_{\text {air }} \times R_{\text {total }}}\right) \mathrm{d} x$

Eqs. (8) and (9) can be expressed as flow:

$$
\left\{\begin{array}{c}
\frac{1}{\left(t_{\text {ground }}-t_{\text {a.in }}\right)} \times \frac{\mathrm{dt}_{\mathrm{a}, \mathrm{in}}}{\mathrm{d} x}-\left(\frac{1}{\mathrm{~m}_{\mathrm{air}} \times \mathrm{C}_{\text {air }} \times R_{\text {total }}}\right)=0 \\
\mathrm{t}_{\mathrm{a}, \mathrm{i}}=t_{\text {ambient }}, \quad x=0
\end{array}\right.
$$

The solution of Eq. (10) gives the following equation to evaluate outlet air temperatures:

$t_{a, \text { out }}=t_{\text {ground }}+\left(t_{\text {a.in }}-t_{\text {ground }}\right) \exp \left(-\frac{L}{m_{\text {air }} \times C_{\text {air }} \times R_{\text {total }}}\right)$

Where $R_{\text {total }}$ is the total thermal resistance of the system, which can be obtained from Eqs. (12) and (13) [52].

$$
R_{\text {total }}=R_{\text {conv }}+R_{\text {cond }}+R_{\text {ground }}
$$

$$
R_{\text {total }}=\frac{1}{\pi \cdot \mathrm{D}_{\text {in,pipe }} \times h_{c}}+\frac{\ln \left(D_{\text {out }, \text { pipe }} / \mathrm{D}_{\text {in,pipe }}\right)}{2 \pi \mathrm{k}_{\text {pipe }}}+\frac{1}{2 \pi \mathrm{k}_{\text {ground }}}\left[\ln \left(\frac{D_{\text {in, pipe }}+D_{\text {out }, \text { ipe }}+d_{\text {constant }}}{D_{\text {in, }, \text { pipe }}+D_{\text {out }, \text { pipe }}}\right)\right]
$$

Where $d_{\text {constant }}$ is boundary condition that ground temperature remains constant beyond this boundary, which is $5 \mathrm{~m}, h_{c}$ is the coefficient of convective heat transfer between air and pipe, which

$$
h_{c}=\left(N u \times \lambda_{a}\right) / 2 r_{i}
$$

35 Nusselt number can be obtained from Eq. (15) [13]. 
$2 N u=0.214 \times\left(R e^{0.8}-100\right) \times \operatorname{Pr}^{0.4}$

The air mass flow rate, Reynolds and Prandtl numbers can be obtained from Eqs. (16) - (18) [52]. 5

$R e=\left(V_{a, p} \times \mathrm{D}_{\text {in,pipe }}\right) / v_{\text {air }}$

$\operatorname{Pr}=\left(C_{\text {air }} \times \mu_{\text {air }}\right) / \lambda_{\text {air }}$

$m_{\text {air }}=\left(\rho_{\text {air }} \times V_{a, p}\left(\pi \cdot D_{\text {in,pipe }}^{2}\right)\right) / 4$

The variables required for numerical calculation of $t_{a, o u t}$ for both climates are presented in Table 3. Values for kinematic viscosity and dynamic viscosity of air are assumed for $26.7\left({ }^{\circ} \mathrm{C}\right)$ 14 temperature.

15

16

17

Table 3

Main parameters to calculate outlet air temperatures.

\begin{tabular}{lll}
\hline Parameter & Value & Unit \\
\hline$t_{\text {a,in }}$ & $\begin{array}{l}\text { Mean daily air temperature } \\
\text { Daily ground temperature }\end{array}$ & $\left({ }^{\circ} \mathrm{C}\right)$ \\
$t_{\text {ground }}$ & $\begin{array}{l}\left.{ }^{\circ} \mathrm{C}\right) \\
\text { at a depth of 5m. }\end{array}$ & $(\mathrm{m})$ \\
$L$ & $10-120$ & $(\mathrm{~m})$ \\
$\mathrm{D}_{\text {in } \text { pipe }}$ & 0.2 & $(\mathrm{~m})$ \\
$D_{\text {out } \text { pipe }}$ & 0.205 & $\left(\mathrm{~W} / \mathrm{m}^{\circ} \mathrm{C}\right)$ \\
$\mathrm{k}_{\text {pipe }}$ & 0.5 & $\left(\mathrm{~W} / \mathrm{m}^{\circ} \mathrm{C}\right)$ \\
$\mathrm{k}_{\text {ground }}$ & 2.1 & $(\mathrm{~m})$ \\
$d_{\text {constant }}$ & 5.0 & $\left(\mathrm{~W} / \mathrm{m}^{2 \circ} \mathrm{C}\right)$ \\
$h_{c}$ & 93.7 & - \\
$N u$ & 729.2 & - \\
Re & 31888 & - \\
$P_{r}$ & 0.71 & $(\mathrm{~m} / \mathrm{s})$ \\
$V_{\text {a,p }}$ & 2.5 & $(\mathrm{~m} / \mathrm{s})$ \\
$v_{\text {air }}$ & $1.568 \times 10^{-5}$ & $\left(\mathrm{~W} / \mathrm{m}^{\circ} \mathrm{C}\right)$ \\
$\lambda_{\text {air }}$ & 0.0257 & $\left(\mathrm{~J} / \mathrm{Kg} \cdot{ }^{\circ} \mathrm{C}\right)$ \\
$C_{\text {air }}$ & 1.0 & $(\mathrm{~kg} / \mathrm{m} \mathrm{s})$ \\
$\mu_{\text {air }}$ & $1.846 \times 10^{-5}$ & $\left(\mathrm{~kg} / \mathrm{m}^{3}\right)$ \\
$\rho_{\text {air }}$ & 1.225 & $(\mathrm{~kg} / \mathrm{s})$ \\
$m_{\text {air }}$ & 0.096 & \\
\hline & &
\end{tabular}

\subsection{Modeling the cooling and heating potential}

20 The potential of EAHEs for cooling, heating, pre-cooling, and pre-heating can be accurately

21 calculated by a mathematical model. The heat flux entering the building through EAHEs can be 22 calculated using the following equation [53].

$24 Q_{E A H E}=m_{\text {air }} \times C_{\text {air }} \times \rho_{\text {air }}\left(t_{a, \text { out }}-t_{a, \text { in }}\right)$ 
1 Where $m_{\text {air }}$ is the air volumetric flow, $C_{\text {air }}$ is the air specific heat at constant pressure, and $\rho_{\text {air }}$

2 is the air density. $t_{a, i n}$ is the inlet air temperature, which is assumed to be equal to ambient air

3 temperature, and $t_{a, o u t}$ is the outlet air temperature of the EAHE system.

\section{5. Model validation}

5 The model developed in this research to predict outlet air temperatures was validated by virtue of

6 two experimental studies being carried out by Dhaliwal et al. [54] for different pipe lengths and

7 Bansal et al. [55] for different inlet air velocities. The main parameters of the both studies are

8 presented in Table 4 and the results of comparison are tabulated in Table 5 and Table 6.

Table 4

12 Input parameters for four comparative validations.

\begin{tabular}{llll}
\hline \multicolumn{1}{c}{ System } & $\begin{array}{l}\text { Experimental data of } \\
\text { Bansal et al.[55] }\end{array}$ & $\begin{array}{l}\text { Experimental data of } \\
\text { Dhaliwal et al.[54] }\end{array}$ & $\begin{array}{l}\text { Theoretical data of } \\
\text { Barakat et al. [52] }\end{array}$ \\
\hline Pipe diameter $(\mathrm{cm})$ & 0.15 & 0.3 & 0.15 and 0.3 \\
Pipe length $(\mathrm{m})$ & 23.42 & 25.00 & 23.42 and 25.00 \\
Air velocity $(\mathrm{m} / \mathrm{s})$ & $2,3,4$ and 5 & 1.5 & $2,3,4,5$ and 1.5 \\
Soil temperature (_C) & 26.7 & 18.89 & 26.7 and 18.89 \\
Pipe depth $(\mathrm{m})$ & - & 2.13 & 2.13 \\
Soil thermal conductivity $(\mathrm{W} / \mathrm{mC})$ & 0.52 & 1.16 & 0.52 and 1.16 \\
Soil thermal diffusivity $\left(\mathrm{m}^{2} / \mathrm{h}\right)$ & - & 0.00232 & 0.00232 \\
\hline
\end{tabular}

As is illustrated, the absolute relative deviation between the reported experimental data and the present model is approximately $7.5 \%$. That is, the maximum difference between the predicted outlet air temperature and the reported data is $1.7^{\circ} \mathrm{C}$ for $24.7 \mathrm{~m}$ pipe length (Table 5), and also when the air velocity inside the buried pipe is $5 \mathrm{~m} / \mathrm{s}$ the relative error accounts for merely $0.2 \%$ (Table 6). Consequently, the mathematical model can properly predict the thermal performance of EAHEs hereafter.

Table 5

Results of model validation against the experimental of Dhaliwal et al. [54].

\begin{tabular}{cccc}
\hline \multirow{2}{*}{$\begin{array}{c}\text { Axial } \\
\text { distance from } \\
\text { the pipe inlet } \\
(\mathrm{m})\end{array}$} & $\begin{array}{c}\text { Experimental data of } \\
\text { Dhaliwal et al.[54] }\end{array}$ & \multicolumn{2}{c}{ Outlet air temperature $\left({ }^{\circ} \mathrm{C}\right)$} \\
\cline { 2 - 4 } & $\mathrm{T}_{\text {out }}\left({ }^{\circ} \mathrm{C}\right)$ & $\mathrm{T}_{\text {out }}\left({ }^{\circ} \mathrm{C}\right)$ & Results of present model \\
\hline 3.35 & 25.0 & 24.91 & 0.36 \\
6.40 & 24.4 & 24.37 & 0.12 \\
9.95 & 25.0 & 23.80 & 4.80 \\
12.50 & 24.4 & 23.43 & 3.97 \\
15.55 & 23.8 & 23.03 & 3.23 \\
24.70 & 23.8 & 22.01 & 7.52 \\
\hline
\end{tabular}


Table 6

2 Results of model validation against the experimental data of Bansal et al. [55].

\begin{tabular}{|c|c|c|c|c|}
\hline \multirow{3}{*}{$\begin{array}{c}\text { Inlet air } \\
\text { velocity }(\mathrm{m} / \mathrm{s})\end{array}$} & \multirow{3}{*}{$\begin{array}{c}\text { Inlet air temperature } \\
\left({ }^{\circ} \mathrm{C}\right)\end{array}$} & \multicolumn{3}{|c|}{ Outlet air temperature $\left({ }^{\circ} \mathrm{C}\right)$} \\
\hline & & \multirow{2}{*}{$\begin{array}{c}\text { Experimental data of } \\
\text { Bansal et al. [55] }\end{array}$} & \multicolumn{2}{|c|}{ Results of present model } \\
\hline & & & $\mathrm{T}_{\text {out }}\left({ }^{\circ} \mathrm{C}\right)$ & Relative error $\%$ \\
\hline 2 & 43.4 & 33.1 & 31.20 & 5.74 \\
\hline 3 & 42.5 & 33.1 & 32.32 & 2.36 \\
\hline 4 & 42.3 & 33.5 & 33.31 & 0.57 \\
\hline 5 & 42.2 & 34.2 & 34.13 & 0.20 \\
\hline
\end{tabular}

3

\section{Results and discussion}

Eq. (4) and Table 2 are used to calculate soil temperature at depths of 0.2, 1.0, 3.0, 5.0 meters for two cities. As Fig.4 shows, in both climates, greater depths exhibit lower temperature variations, lower maximum soil temperatures, and higher minimum soil temperatures, as these values approach the annual average. As the results show, the amplitude of the soil temperature decreases with depth, so that the soil temperature amplitude at the depths of 1.0,3.0 and $5.0 \mathrm{~m}$ is respectively 10.2, 5.7 and $3.2^{\circ} \mathrm{C}$ in Yazd and $8.8,4.9$ and $2.7^{\circ} \mathrm{C}$ in Hamadan. Ultimately, this parameter approaches zero at a depth of $14 \mathrm{~m}$ in Yazd and $13.2 \mathrm{~m}$ in Hamadan. At these depths, the soil temperature reaches the constant values of $18.2{ }^{\circ} \mathrm{C}$ for Yazd and $12.1^{\circ} \mathrm{C}$ for Hamadan.

In Yazd (Figure 4-a) the maximum and minimum temperatures at a depth of $1 \mathrm{~m}$ are, respectively $28.4{ }^{\circ} \mathrm{C}$ and $7.6{ }^{\circ} \mathrm{C}$; but at a depth of $4 \mathrm{~m}$, these values are respectively $21.2^{\circ} \mathrm{C}$ and $14.8^{\circ} \mathrm{C}$. Fig. 4-b, which shows the variation of soil temperature at different depths for the city of Hamadan, also indicates that a $4 \mathrm{~m}$ increase in depth raises the minimum temperature and decreases the maximum temperature by $7.4^{\circ} \mathrm{C}$.

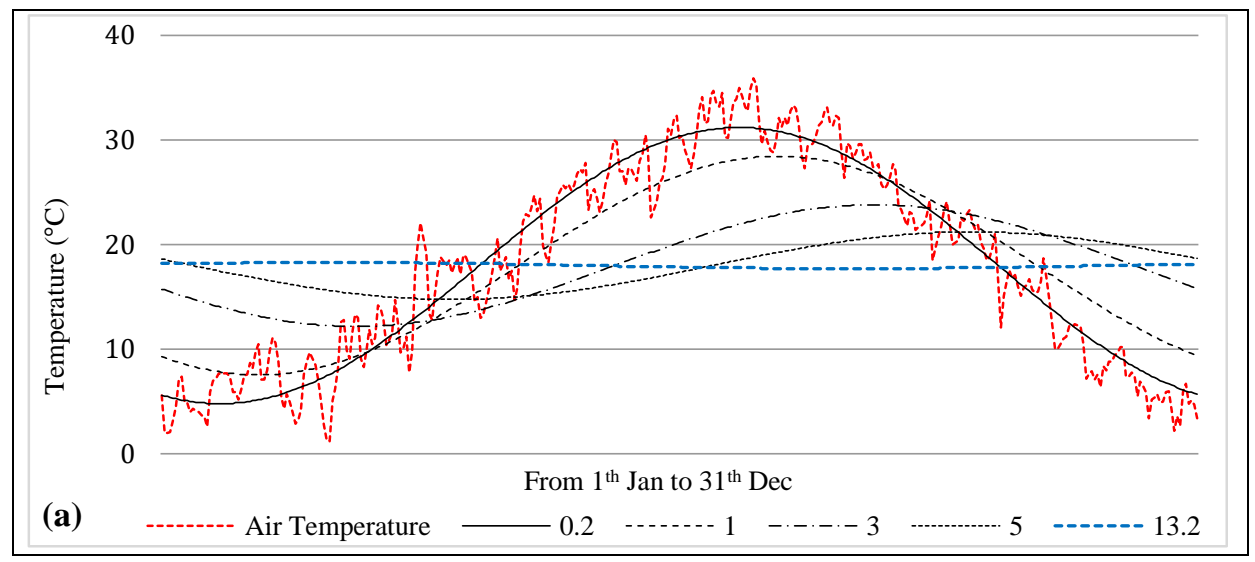




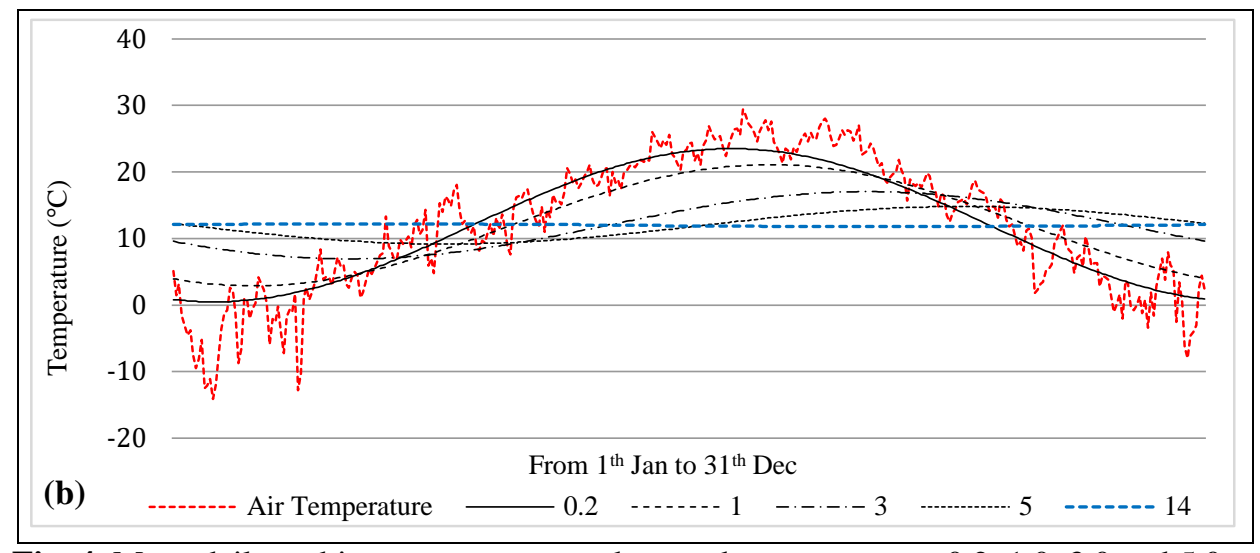

Fig. 4. Mean daily ambient temperature and ground temperature at $0.2,1.0,3.0$ and $5.0 \mathrm{~m}$ depth, (a): Yazd, (b): Hamadan

According to Fig. 4, a depth of $5 \mathrm{~m}$ is selected as the optimal depth for the placement of EAHE pipes since it has lower fluctuations rather than the other depths. Data from Table 3, Fig. 4 and Eqs. (6) - (18) are used to calculate the outlet air temperature of EAHE systems with pipes of different lengths and different inlet air temperatures for both climates.

Fig. 5 shows the relationship between the inlet air temperature and pipe length at a depth of $5 \mathrm{~m}$. the intersection of horizontal and vertical axes represents the outlet air temperature of the EAHE system. In Fig. 5, green cells indicate that the outlet air temperature is within the range of thermal comfort $\left(18-23^{\circ} \mathrm{C}[56]\right)$ and can be directly used for cooling or heating the interior space, blue tones mark the range in which EAHEs operate as a pre-heater, and red tones signify the range in which they act as a pre-cooler. As is shown, in both climates, the pre-heating efficiency of the system is greater than its pre-cooling efficiency. According to the data, in both climates, this system can be generally used throughout the year; however, it is most efficient in terms of compliance of the outlet air temperature, within the comfort zone over $20^{\circ} \mathrm{C}$ for Yazd and over $25^{\circ} \mathrm{C}$ for Hamadan.

As Fig. 5 shows, the efficacy of EAHE rises with an increase in pipe length. Additionally, when the air temperature of Yazd and Hamadan is higher than $20^{\circ} \mathrm{C}$ and $15^{\circ} \mathrm{C}$, respectively, an increase in pipe length leads to a lower outlet air temperature(cooling), but for temperatures below $15^{\circ} \mathrm{C}$ and $10^{\circ} \mathrm{C}$ for Yazd and Hamadan, the outlet air temperature increases with an augmentation in pipe length (heating).

When inlet air temperature equal to the temperatures of the coldest days in Yazd and Hamadan, i.e. 0.8 and $-11^{\circ} \mathrm{C}$, the EAHE system with a pipe length of $120 \mathrm{~m}$ can increase the temperature by $13^{\circ} \mathrm{C}$ and $17.9^{\circ} \mathrm{C}$ respectively; and taking that the inlet air temperature is equal to the temperatures of the warmest days in Yazd and Hamadan, i.e. 38.8 and $30.7^{\circ} \mathrm{C}$, the same EAHE can decrease the temperature by $15.7^{\circ} \mathrm{C}$ and $14.5^{\circ} \mathrm{C}$ respectively. 


\begin{tabular}{|c|c|c|c|c|c|c|c|c|c|c|c|c|c|}
\hline \multirow{12}{*}{ 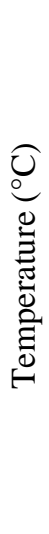 } & -15 & -11.2 & -7.9 & -4.9 & -2.3 & 0.0 & 2.1 & 3.9 & 5.5 & 6.9 & 8.2 & 9.3 & 10.3 \\
\hline & -10 & -6.8 & -4.0 & -1.5 & 0.8 & 2.7 & 4.5 & 6.0 & 7.4 & 8.6 & 9.7 & 10.6 & 11.5 \\
\hline & -5 & -2.4 & 0.0 & 2.0 & 3.8 & 5.5 & 6.9 & 8.2 & 9.3 & 10.3 & 11.2 & 12.0 & 12.6 \\
\hline & 0 & 2.1 & 3.9 & 5.5 & 6.9 & 8.2 & 9.3 & 10.3 & 11.2 & 12.0 & 12.7 & 13.3 & 13.8 \\
\hline & +5 & 6.5 & 7.8 & 9.0 & 10.0 & 10.9 & 11.7 & 12.4 & 13.1 & 13.6 & 14.1 & 14.6 & 15.0 \\
\hline & +10 & 10.9 & 11.7 & 12.4 & 13.1 & 13.6 & 14.1 & 14.6 & 15.0 & 15.3 & 15.6 & 15.9 & 16.1 \\
\hline & +15 & 15.3 & 15.6 & 15.9 & 16.2 & 16.4 & 16.6 & 16.7 & 16.9 & 17.0 & 17.1 & 17.2 & 17.3 \\
\hline & +20 & 19.8 & 19.6 & 19.4 & 19.2 & 19.1 & 19.0 & 18.9 & 18.8 & 18.7 & 18.6 & 18.5 & 18.5 \\
\hline & +25 & 24.2 & 23.5 & 22.9 & 22.3 & 21.8 & 21.4 & 21.0 & 20.6 & 20.3 & 20.1 & 19.8 & 19.6 \\
\hline & +30 & 28.6 & 27.4 & 26.3 & 25.4 & 24.5 & 23.8 & 23.1 & 22.5 & 22.0 & 21.6 & 21.2 & 20.8 \\
\hline & +35 & 33.1 & 31.3 & 29.8 & 28.5 & 27.3 & 26.2 & 25.3 & 24.4 & 23.7 & 23.0 & 22.5 & 22.0 \\
\hline & +40 & 37.5 & 35.3 & 33.3 & 31.5 & 30.0 & 28.6 & 27.4 & 26.3 & 25.4 & 24.5 & 23.8 & 23.1 \\
\hline & & $10 \mathrm{~m}$ & $20 \mathrm{~m}$ & $30 \mathrm{~m}$ & $40 \mathrm{~m}$ & $50 \mathrm{~m}$ & $\begin{array}{l}60 \mathrm{~m} \\
\text { Pipe le }\end{array}$ & $\begin{array}{l}70 \mathrm{~m} \\
\text { th }(\mathrm{m})\end{array}$ & $80 \mathrm{~m}$ & $90 \mathrm{~m}$ & $100 \mathrm{~m}$ & $110 \mathrm{~m}$ & $120 \mathrm{~m}$ \\
\hline
\end{tabular}

\begin{tabular}{|c|c|c|c|c|c|c|c|c|c|c|c|c|}
\hline-15 & -11.9 & -9.2 & -6.8 & -4.6 & -2.7 & -1.0 & 0.5 & 1.8 & 2.9 & 4.0 & 4.9 & 5.7 \\
\hline-10 & -7.5 & -5.3 & -3.3 & -1.5 & 0.0 & 1.4 & 2.6 & 3.7 & 4.6 & 5.5 & 6.2 & 6.9 \\
\hline-5 & -3.1 & -1.3 & 0.2 & 1.5 & 2.7 & 3.8 & 4.7 & 5.6 & 6.3 & 7.0 & 7.5 & 8.0 \\
\hline 0 & 1.4 & 2.6 & 3.7 & 4.6 & 5.5 & 6.2 & 6.9 & 7.5 & 8.0 & 8.4 & 8.8 & 9.2 \\
\hline+5 & 5.8 & 6.5 & 7.1 & 7.7 & 8.2 & 8.6 & 9.0 & 9.4 & 9.7 & 9.9 & 10.2 & 10.4 \\
\hline+10 & 10.2 & 10.4 & 10.6 & 10.8 & 10.9 & 11.0 & 11.1 & 11.2 & 11.3 & 11.4 & 11.5 & 11.5 \\
\hline+15 & 14.7 & 14.4 & 14.1 & 13.8 & 13.6 & 13.4 & 13.3 & 13.1 & 13.0 & 12.9 & 12.8 & 12.7 \\
\hline+20 & 19.1 & 18.3 & 17.6 & 16.9 & 16.4 & 15.9 & 15.4 & 15.0 & 14.7 & 14.4 & 14.1 & 13.9 \\
\hline+25 & 23.5 & 22.2 & 21.0 & 20.0 & 19.1 & 18.3 & 17.6 & 16.9 & 16.4 & 15.9 & 15.4 & 15.0 \\
\hline+30 & 27.9 & 26.1 & 24.5 & 23.1 & 21.8 & 20.7 & 19.7 & 18.8 & 18.0 & 17.3 & 16.7 & 16.2 \\
\hline+35 & 32.4 & 30.0 & 28.0 & 26.2 & 24.5 & 23.1 & 21.8 & 20.7 & 19.7 & 18.8 & 18.0 & 17.4 \\
\hline+40 & 36.8 & 34.0 & 31.5 & 29.2 & 27.3 & 25.5 & 24.0 & 22.6 & 21.4 & 20.3 & 19.4 & 18.5 \\
\hline (b) & $10 \mathrm{~m}$ & $20 \mathrm{~m}$ & $30 \mathrm{~m}$ & $40 \mathrm{~m}$ & $50 \mathrm{~m}$ & $\begin{array}{l}60 \mathrm{~m} \\
\text { Pipe le }\end{array}$ & $70 \mathrm{~m}$ & $80 \mathrm{~m}$ & $90 \mathrm{~m}$ & $100 \mathrm{~m}$ & $110 \mathrm{~m}$ & $120 \mathrm{~m}$ \\
\hline
\end{tabular}

Fig. 5. Impact of pipe length and inlet temperature on EAHE performance (a): Yazd (ground temperature: $18.2^{\circ} \mathrm{c}$ ), (b): Hamadan (ground temperature: $12.1^{\circ} \mathrm{c}$ )

Table 3, Fig. 4 and Eqs. (6) - (18) are used to calculate the outlet air temperature of the EAHE system with 30, 60 and $90 \mathrm{~m}$ pipe lengths buried at a depth of $5 \mathrm{~m}$ for both climates. Numerical results obtained for cold and warm months in these cities are illustrated in Fig. 6. The results show that the use of the EAHE with a pipe length of 30, 60 and $90 \mathrm{~m}$ in Yazd during the warm season (1 Jun- $31 \mathrm{Sep}$ ) decreases the average outlet air temperature by respectively $3.04,5.16$ and $6.06^{\circ} \mathrm{C}$, or $11 \%, 18 \%$ and $23 \%$. In addition, the modeled EAHE provides a profitable heating performance in Yazd (the hot- arid climate). During the cold season of Yazd (1 Dec- 31 Jun), this system, with pipe lengths of 30,60 and $90 \mathrm{~m}$, leads to a $41 \%, 54 \%$ and $60 \%$ increase in outlet air temperatures. Results show, this system can work as a cooler, heater, pre-cooler and pre-heater in hot and dry region (Yazd city). The impact of the different pipe length on the EAHE performance during the cold and warm months is shown in Fig. 6-a and 6-b.

According to Fig. 6-c, during the warm season in the city of Hamadan (1 July- 31 Aug), the EAHE with pipe lengths of 30,60 and $90 \mathrm{~m}$ can reduce the average outlet air temperature by $14 \%, 24 \%$ 
and 31\%, respectively. Moreover, during the cold season of this city (1 Nov- $31 \mathrm{Feb}$ ), the use of EAHE systems with pipe lengths of 30, 60 and 90 m leads to the outstanding result of an $82 \%$, $88 \%$ and $91 \%$ improvement in the average outlet air temperature, see Fig. 6-d. This system, in general, demonstrated an acceptable performance for both heating and cooling purposes in cold climate.

(a) 18 (a)

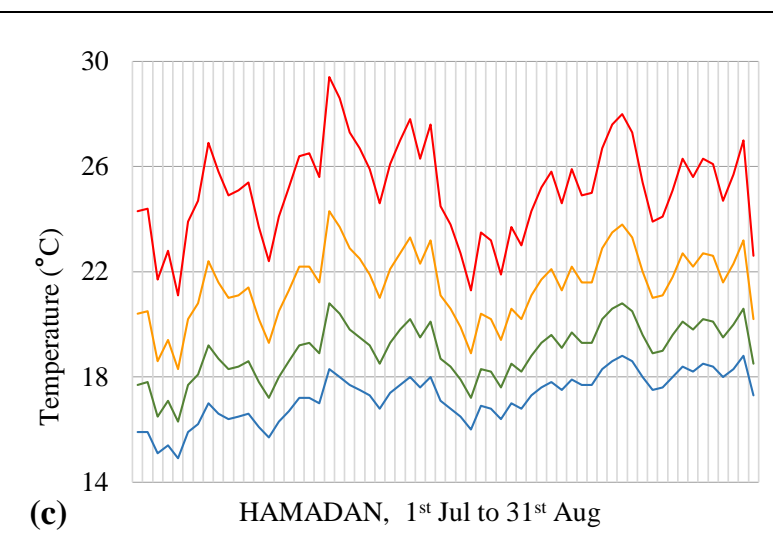

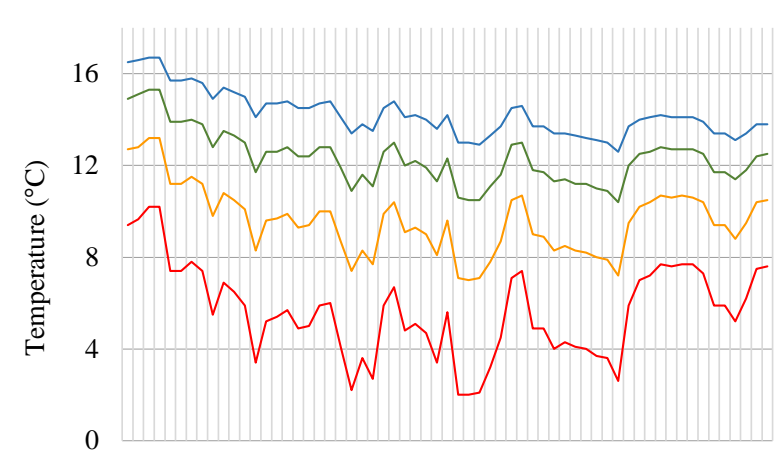

(b)

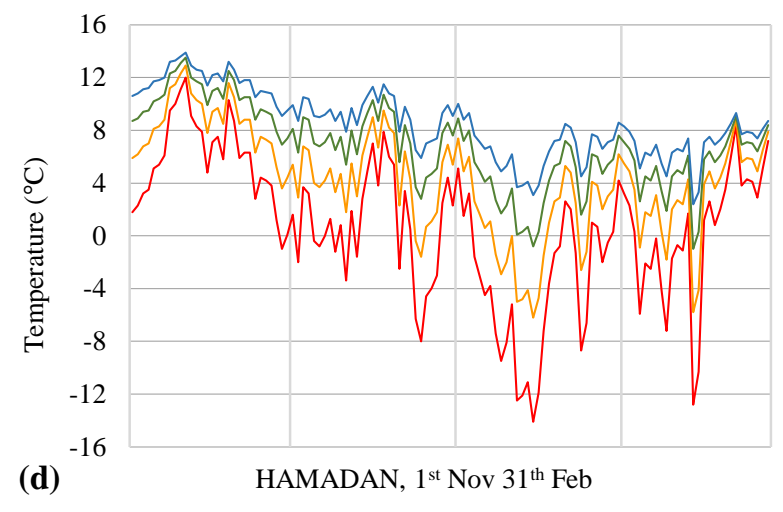

30 m Pipe 90m Pipe

Fig. 6. Mean daily outlet air temperatures EAHE in comparison with inlet air temperature, (a): Warm season of YAZD, (b): Cold season of YAZD, (c): Warm season of HAMADAN, (d): Cold season of HAMADAN

For both climates, the EAHE works as a heater in Jun, Feb, March, Nov and December, and as a cooler in May, Jun, July, Aug and Sep. The best performance of the EAHE to decrease inlet air temperature occurs in July with $9.3^{\circ} \mathrm{C}$ and $8.6^{\circ} \mathrm{C}$ reduction for Yazd and Hamadan, respectively. Moreover, the highest performance of the modeled EAHE to work as a heater takes place in Dec with an $8.8^{\circ} \mathrm{C}$ increase of the inlet air temperature for Yazd, and in January for Hamadan. Results show that this system increases the average inlet air temperature for Hamadan around $10.2^{\circ} \mathrm{C}$. Fig. $7 \mathrm{a}$ and $7 \mathrm{~b}$ show the mean monthly inlet air temperature (the ambient air temperature) in comparison with the mean monthly outlet air temperature. 


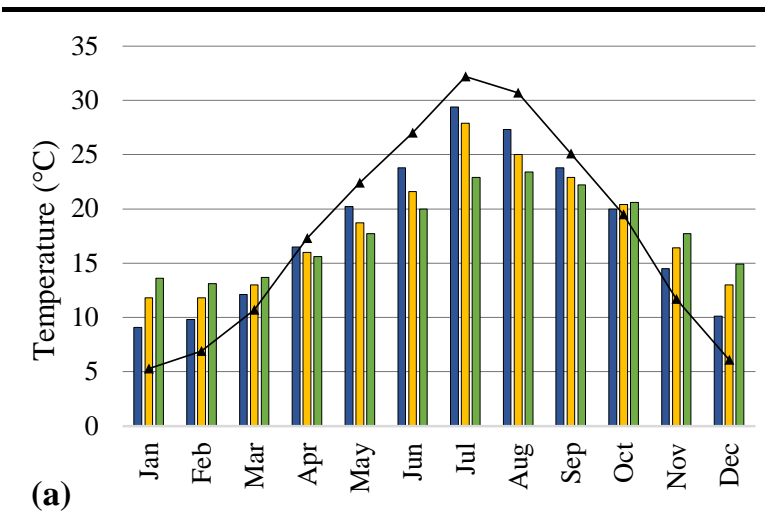

(a)

\30 m $\square 60 \mathrm{~m} \square 90 \mathrm{~m} \longrightarrow$ Inlet air temperature

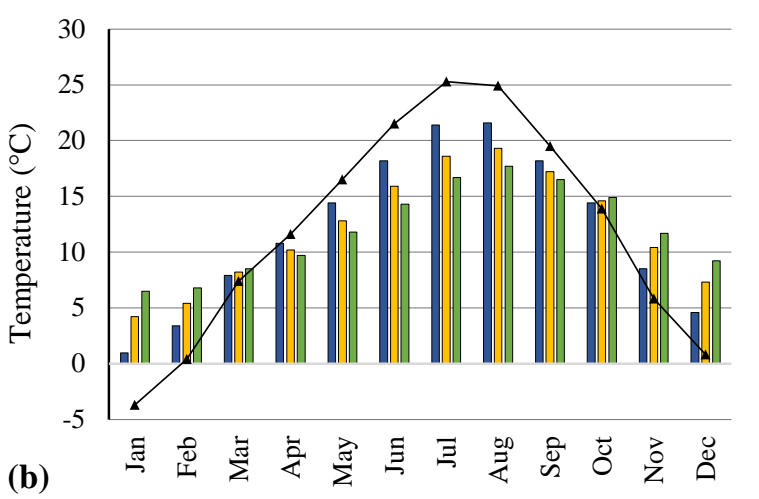

(b)

$\square 30 \mathrm{~m} \square 60 \mathrm{~m} \square 90 \mathrm{~m} \longrightarrow$ Inlet air temperature

Fig.7. Mean monthly outlet air temperature of EAHE at $5.0 \mathrm{~m}$ depth in comparison with inlet air temperature, (a): YAZD, (b): HAMADAN.

According to the results, a pipe length of $90 \mathrm{~m}$ seems to provide the highest efficiency during the cold and warm seasons. Table 3, Fig. 4 and Eqs. (6) - (18) are employed to calculate the fluctuations of the outlet air temperature of an EAHE system with a $90 \mathrm{~m}$ length of pipe buried at a depth of $5 \mathrm{~m}$. The results show the ability of this system to not only reduce the difference between the maximum and minimum inlet air temperatures, but also to reduce the temperature fluctuations, and to push them closer to the range of thermal comfort.

10 Throughout the year, as depicted in Fig. 8, using a $90 \mathrm{~m}$ pipe length at $5 \mathrm{~m}$ depth, daily fluctuation

11 of outlet air temperatures is compared with the fluctuations of the inlet air temperature in the cities 12 of Yazd and Hamadan.

13 In Yazd, using the EAHE reduces the difference between the maximum and minimum inlet air 14 temperatures by $66 \%$. This means a 9.79 and $3.23{ }^{\circ} \mathrm{C}$ decrease in the average maximum and 15 minimum air temperatures during the warm season and a 6.30 and $10.25^{\circ} \mathrm{C}$ increase in the average 16 maximum and minimum air temperatures during the cold season. For the city of Hamadan, these 17 values are 3.15 and $2.14{ }^{\circ} \mathrm{C}$ for the warm season and 4.05 and $10.96^{\circ} \mathrm{C}$ for the cold season, 18 respectively. In Hamadan, in the case of using the described EAHE system, the difference between 19 the maximum and minimum outlet air temperatures decreases to about one-third of its normal 20 value. Consequently, the annual average of minimum and maximum daily temperatures changes 21 from 18.99 and $5.43^{\circ} \mathrm{C}$ to 14.38 and $9.84^{\circ} \mathrm{C}$. 

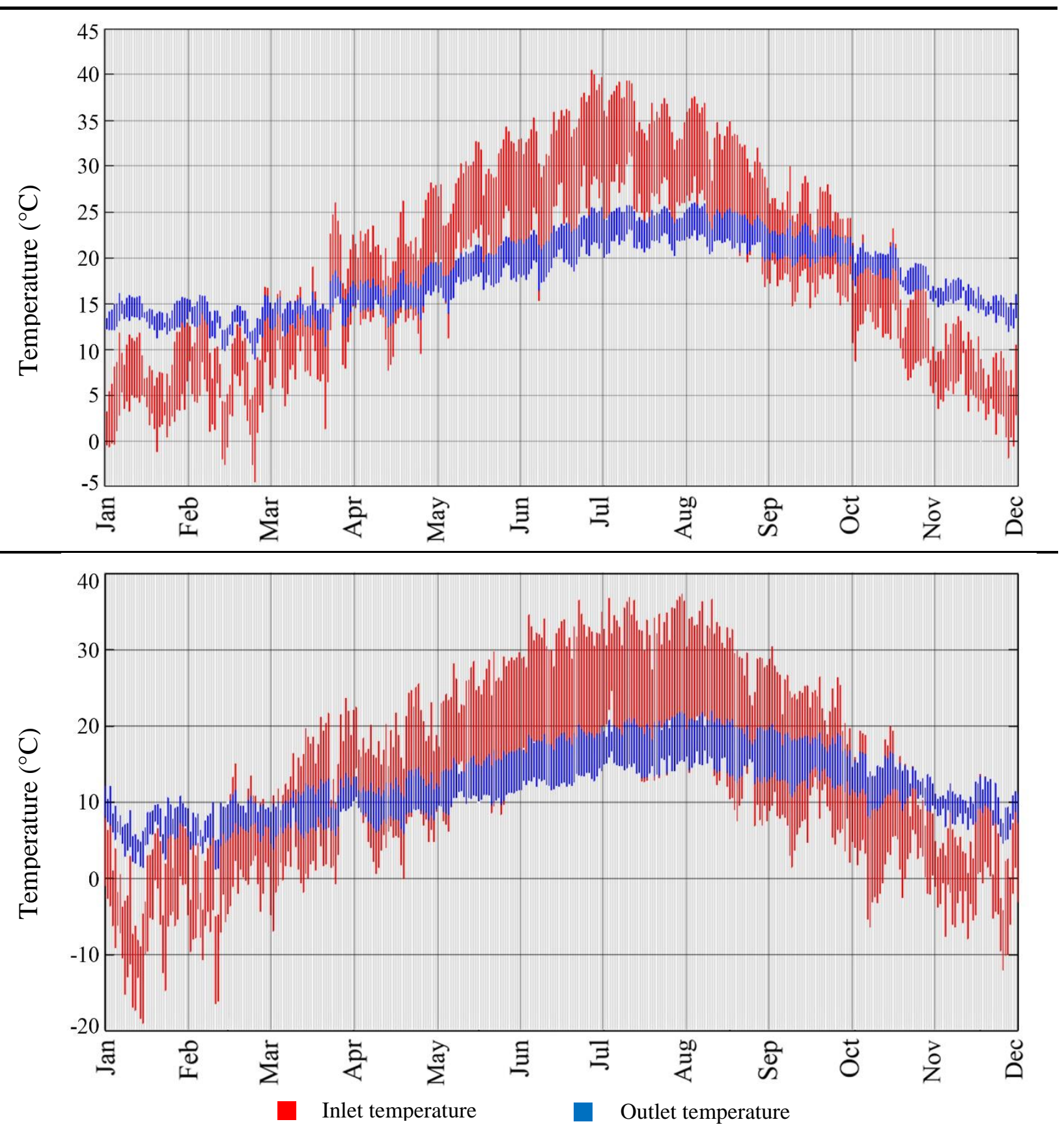

From $1^{\text {st }}$ Jan to $31^{\text {st }}$ Dec

\footnotetext{
Fig. 8. Minima and maxima of the outlet air temperature in comparison with minima and maxima of the inlet air temperature, (a): YAZD, (b): HAMADAN
}

4 Knowing the outlet air temperature of the EAHE system by using a $90 \mathrm{~m}$ pipe, the cooling, heating, 5 pre-cooling and pre-heating potentials of this system can be estimated. When the temperature of 6 outlet air is within the range of thermal comfort, this air can be used directly for heating/cooling; 7 otherwise, it must be used for pre-heating /pre-cooling.

8 Fig. 9 shows the number of days and months during which the EAHE system can be used for 9 cooling, heating, pre-cooling and pre-heating in these climates. Here, the term "out of work" refers 
to the days when the EAHE system cannot change the inlet air temperature or pushes the 2 temperature away from the range of thermal comfort. During Mar-Oct, for instance, this system is 3 not feasible for use in the cold climate, as the outside air temperature is already within the range 4 of thermal comfort.

5 As Fig. 9 and Table 7 show, for both cold and hot-dry climates, the EAHE system exhibits the highest potential for pre-heating and lowest potential for heating. The only employment of this system for heating is in Yazd in a period of 19 days during Oct-Nov, when it can push the mild temperature of the fall into the range of thermal comfort. Meanwhile, owing to the cold climate of Hamadan, the EAHE system has no pre-cooling and heating potentials, it can be used for the cooling purposes during 56 days of summer; thus, reducing the cooling load by $4869.6 \times 103 \mathrm{kWh}$. In Yazd, the impact of the EAHE system on cooling loads is more significant; i.e. this system can be used for cooling and pre-cooling for a period of 128 days, resulting in a $15888 \times 10^{3} \mathrm{kWh}$ 13 reduction in cooling loads.

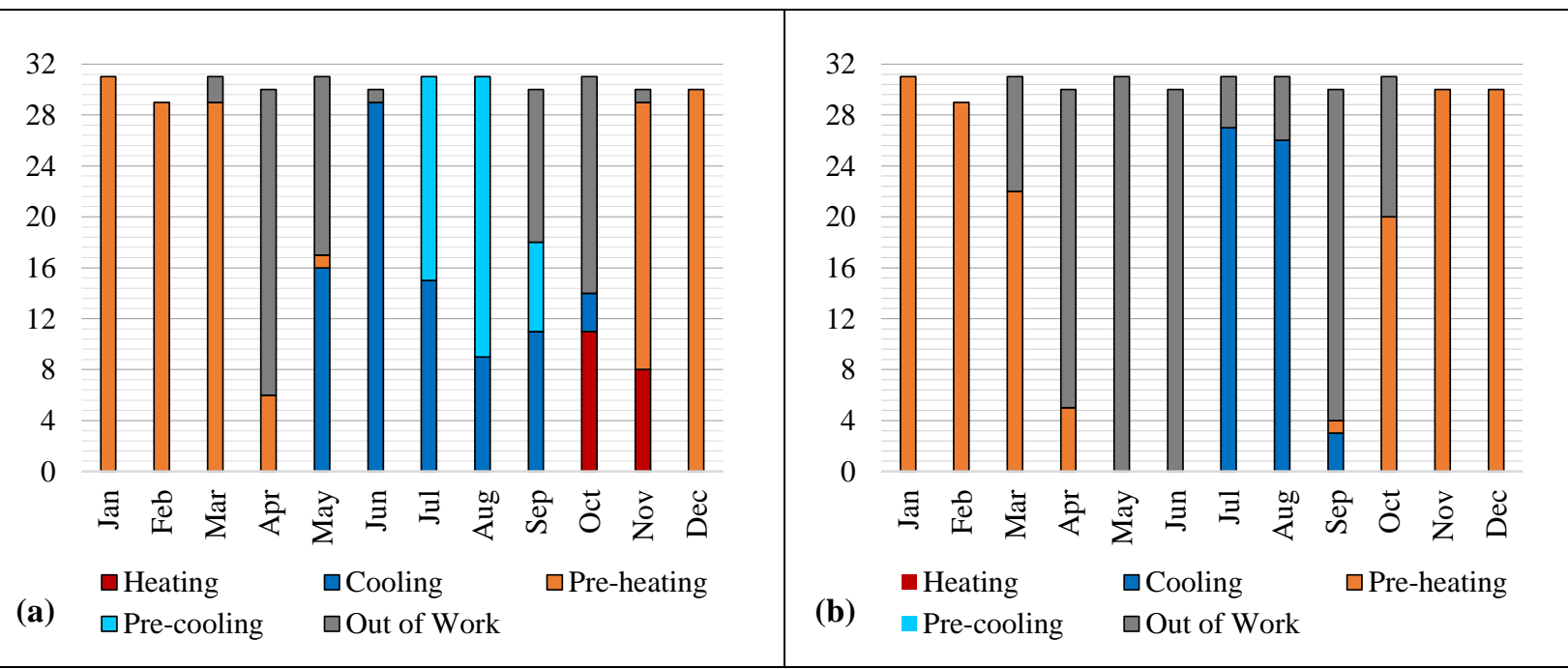

Fig. 9. Number of days using EAHE for cooling, heating, pre-cooling and pre-heating, (pipe length: $90 \mathrm{~m}$, depth: 5m) (a): Yazd (Hot and Dry), (b): Hamadan (Cold)

Overall, this system exhibits a more superior performance in heating than in other applications. According to Table 7, in both cities, the most frequent use of the system will be for pre-heating. This table shows that EAHEs can be used on 147 days in Yazd and 169 days in Hamadan for preheating, which leads to, respectively, a $10202.4 \times 103 \mathrm{kWh}$ and $11167.2 \times 103 \mathrm{kWh}$ reduction in heating loads. The EAHE system is more efficient in the hot and dry climate than the cold climate; that is, in Yazd it can be used on 294 days of the year and contribute to a $19966.3 \times 10^{3} \mathrm{kWh}$ energy saving, which is greater than the $16036.8 \times 10^{3} \mathrm{kWh}$ energy which it can save during 225 days when used in Hamadan. 
Table 7

2 Total energy saving (kWh) by EAHE systems during a year (pipe length: $90 \mathrm{~m}$, depth: $5 \mathrm{~m}$ )

\begin{tabular}{ccccc}
\hline \multirow{2}{*}{ City } & \multicolumn{4}{c}{ Total Energy Saving $(\mathrm{kWh})$} \\
\cline { 2 - 5 } & Heating & Cooling & Pre-heating & Pre-cooling \\
\hline Yazd (Hot and Dry) & $72.7 \times 10^{3}$ & $5685.6 \times 10^{3}$ & $10202.4 \times 10^{3}$ & $4005.6 \times 10^{3}$ \\
Day & 19 & 83 & 147 & 45 \\
\hline Hamadan (Cold) & - & $4869.6 \times 10^{3}$ & $11167.2 \times 10^{3}$ & - \\
Day & 0 & 56 & 169 & 0 \\
\hline
\end{tabular}

Eq. (19) is used to calculate the average monthly energy saving of the EAHE system with a $90 \mathrm{~m}$ pipe buried at a depth of $5 \mathrm{~m}$, which is shown in Table 8 . In this table, positive values represent the ability of the system to reduce cooling/heating loads, and negative values indicate that using the system raises the energy demand of the building. As can be seen, the greatest average energy saving ( $4165 \mathrm{kWh})$ pertains to July. Furthermore, this system exhibits a great potential for reducing the heating load during the cold months (Jun and Dec) of the hot and arid climate. The results also show that utilizing this system in Apr and May increases the heating load.

11 For the city of Hamadan the desirable heating efficiency of EAHEs pertains to the months Jan and 12 Dec, with an energy savings of 4594 and $3741 \mathrm{kWh}$, respectively. It is important to note that the 13 use of EAHEs during Apr, May, Jun and Sep is counterproductive, as it will increase the energy 14 loss of the building. According to the results, total energy saving of the EAHE system for a year 15 is 50.1-63.6\% for Yazd and 24.5-47.9\% for Hamadan.

Table 8

Mean monthly inlet and outlet air temperatures $\left({ }^{\circ} \mathrm{c}\right)$ and energy exchange between the air and the ground $(\mathrm{kWh})$.

\begin{tabular}{ccccccccccccccc}
\hline City & Jan & Feb & Mar & Apr & May & Jun & Jul & Aug & Sep & Oct & Nov & Dec \\
\hline & Inlet temperature & 5.4 & 6.7 & 11.3 & 17.2 & 22.6 & 27.2 & 32.2 & 30.6 & 24.8 & 19.4 & 11.5 & 6.0 \\
\hline & Outlet temperature & 13.6 & 13.1 & 13.9 & 15.6 & 17.8 & 20.1 & 22.9 & 23.4 & 22.2 & 20.6 & 17.6 & 14.9 \\
\hline & Energy exchange & +3694 & +2830 & +1305 & -867 & -2167 & +3177 & +4165 & +3221 & +1265 & +813 & +2725 & +4002 \\
\hline & Inlet temperature & -3.8 & 0.6 & 7.4 & 11.9 & 16.7 & 21.6 & 25.4 & 24.9 & 19.2 & 13.6 & 5.8 & 0.8 \\
\hline
\end{tabular}

The EAHE has higher potential to act as cooler in Yazd (the hot-dry climate) that of Hamadan (the cold climate) as heater in. The ground temperature and EAHE potential for both cities are summarized and compared in Table 9. 
Table 9

2 Implementation of EAHEs (pipe length: 90m, depth: 5m) in Yazd (hot-dry climate) and Hamadan (cold climate)

\begin{tabular}{|c|c|c|c|c|}
\hline Item & Yazd & Hamadan & Description & Unit \\
\hline Climate & Hot-dry & Cold & - & - \\
\hline Min ground temperature & 14.8 & 9.2 & \multirow{2}{*}{ at a $5 \mathrm{~m}$ depth } & \multirow{2}{*}{${ }^{\circ} \mathrm{C}$} \\
\hline Max ground temperature & 21.2 & 14.8 & & \\
\hline Depth of constant ground temperature & 13.2 & 14.0 & - & $\mathrm{m}$ \\
\hline $\begin{array}{l}\text { Increase of inlet air temperature } \\
\text { (heating) }\end{array}$ & $0.2-11.2$ & $0.1-17.2$ & \multirow{2}{*}{$\min -\max$} & \multirow{2}{*}{${ }^{\circ} \mathrm{c}$} \\
\hline $\begin{array}{l}\text { Decrease of inlet air temperature } \\
\text { (cooling) }\end{array}$ & $1.3-11.4$ & $5.7-11.1$ & & \\
\hline Cooling potential & $628-4485$ & $2556-4978$ & \multirow{2}{*}{$\min -\max$} & \multirow{5}{*}{$\mathrm{kWh}$} \\
\hline Heating potential & $1031-2691$ & 0 & & \\
\hline Pre-cooling potential & $2018-5113$ & 0 & \multirow{2}{*}{$\min -\max$} & \\
\hline Pre-heating potential & $90-5023$ & $45-7714$ & & \\
\hline Total energy saving & $19966.3 \times 10^{3}$ & $16036.8 \times 10^{3}$ & during a year & \\
\hline Number of day & 294 & 225 & $\begin{array}{l}\text { EAHE can be used as cooler, } \\
\text { heater, pre-cooler and pre- } \\
\text { heater. }\end{array}$ & day \\
\hline Highest heating energy saving & December & January & $\begin{array}{l}\text { The maximum heating energy } \\
\text { saving during a year, including } \\
\text { heating and pre-heating }\end{array}$ & \multirow{4}{*}{ month } \\
\hline Lowest heating energy saving & May & March & $\begin{array}{l}\text { The minimum heating energy } \\
\text { saving during a year, including } \\
\text { heating and pre-heating. }\end{array}$ & \\
\hline Highest cooling energy saving & July & July & $\begin{array}{l}\text { The maximum heating energy } \\
\text { saving during a year, including } \\
\text { cooling and pre-cooling. }\end{array}$ & \\
\hline Lowest cooling energy saving & September & September & $\begin{array}{l}\text { The minimum heating energy } \\
\text { saving during a year, including } \\
\text { cooling and pre-cooling. }\end{array}$ & \\
\hline
\end{tabular}

\section{Conclusion}

In this paper, a numerical model developed with MATLAB was used to examine and compare energy saving potential of EAHE in hot-dry and cold climates in Iran. First, the ground temperature at different depths of Yazd(hot-dry) and Hamadan(cold) was examined. Afterwards, the model was developed for high-density polyethylene pipes of different lengths based on a fixed pipe diameter, constant air flow rates, and pipe burial depths.

10 The results, showed that soil temperature fluctuations decrease with depth until reaching the 11 constant annual averages of $18.2^{\circ} \mathrm{C}$ at the depth of $13.2 \mathrm{~m}$ in Yazd, and $12.1^{\circ} \mathrm{C}$ at a depth of $14 \mathrm{~m}$ 12 in Hamadan. The amplitude of the soil temperature decreases with depth, so that at a depth of 1.0, 133.0 and $5.0 \mathrm{~m}$ it accounts for, respectively, 10.2, 5.7 and $3.2^{\circ} \mathrm{C}$ in $\mathrm{Yazd}$ and $8.8,4.9$ and $2.7^{\circ} \mathrm{C}$ in 14 Hamadan.

15 Earth to air heat exchanger(EAHE) system can be used in both cities for heating and cooling 16 purposes, but it is most efficient in terms of outlet temperatures meeting the thermal comfort 17 criteria, when the air temperature is over $20^{\circ} \mathrm{C}$ in Yazd or over $25^{\circ} \mathrm{C}$ in Hamadan. The effect of 18 this system in reducing the difference between minimum and maximum temperatures varied with 19 climates, i.e. in the hot-arid climate, this system triggered a $66 \%$ reduction in the difference 20 between the maximum and minimum daily temperatures throughout the year; whereas, in the cold 
climate, it decreased the average maximum and minimum temperatures during the warm season by 3.15 and $2.14^{\circ} \mathrm{C}$ and increased these values during the cold season by 4.05 and $10.96^{\circ} \mathrm{C}$. In both cities, the most frequent use of the system would be for pre-heating and it is more efficient in hot and arid climates than in cold climates. This is since in Yazd, the system can be used on 294 days of the year and save $19966.3 \times 10^{3} \mathrm{kWh}$ of energy which is equivalent with $50.1-63.6 \%$ energy saving, with the greatest saving being in July (reduction of cooling loads); however, in Hamadan it can be used on 225 days of the year and save $16036.8 \times 10^{3} \mathrm{kWh}$, resulting in a reduction of energy consumption by $24.5-47.9 \%$, with the greatest saving being in January (reduction of heating loads). As results showed, EAHEs have higher potential to act as cooler in hot-dry climates rather than as a heater in cold climates.

\section{References}

[1] Luo Z, Zhao J, Yao R, Shu Z. Emergy-based sustainability assessment of different energy options for green buildings. Energy Convers Manage 2015;100:97-102.

[2] Angrisani G, Canelli M, Roselli C, Sasso M. Microcogeneration in buildings with low energy demand in load sharing application. Energy Convers Manage 2015;100:78-89.

[3] Goudarzi H, Mostafaeipour A. Energy saving evaluation of passive systems for residential buildings in hot and dry regions. Renew Sustain Energy Rev 2017;68, Part 1:432-446.

[4] Kojok F, Fardoun F, Younes R, Outbib R. Hybrid cooling systems: A review and an optimized selection scheme. Renew Sustain Energy Rev 2016;65:57-80.

[5] Soflaei F, Shokouhian M, Abraveshdar H, Alipour A. The impact of courtyard design variants on shading performance in hot- arid climates of Iran. Energy Build 2017,143:71-83.

[6] Soflaei F, Shokouhian M, Zhu W. Socio-environmental sustainability in traditional courtyard houses of Iran and China. Renew Sustain Energy Rev 2017;69:1147-1169.

[7] Farmahini-Farahani M, Delfani S, Esmaeelian J. Exergy analysis of evaporative cooling to select the optimum system in diverse climates. Energy 2012;40:250-257.

[8] Krarti M, Kreider JF. Analytical model for heat transfer in an underground air tunnel. Energy Convers Manage 1996,37:1561-1574.

[9] Thakur AKS, Musa Momoh M. Temperature variation in upper earth crust due to periodic nature of solar insolation. Energy Convers Manage 1983,23:131-134.

[10] Van Dronkelaar C, Cóstola D, Mangkuto RA, Hensen JLM. Heating and cooling energy demand in underground buildings: Potential for saving in various climates and functions. Energy Build 2014;71:129136.

[11] Niu F, Yu Y, Yu D, Li H. Heat and mass transfer performance analysis and cooling capacity prediction of earth to air heat exchanger. Appl Energy 2015;137:211-221.

[12] Peretti C, Zarrella A, De Carli M, Zecchin R. The design and environmental evaluation of earth-to-air heat exchangers (EAHE). A literature review. Renew Sustain Energy Rev 2013;28:107-116.

[13] Tittelein P, Achard G, Wurtz E. Modelling earth-to-air heat exchanger behaviour with the convolutive response factors method. Appl Energy 2009;86:1683-1691.

[14] Benhammou M, Draoui B. Parametric study on thermal performance of earth-to-air heat exchanger used for cooling of buildings. Renew Sustain Energy Revi 2015;44:348-355.

[15] Breesch H, Bossaer A, Janssens A. Passive cooling in a low-energy office building. Sol Energy 2005;79:682696.

[16] Wu H, Wang S, Zhu D. Modelling and evaluation of cooling capacity of earth-air-pipe systems. Energy Convers Manage 2007;48:1462-1471.

[17] Kumar R, Ramesh S, Kaushik SC. Performance evaluation and energy conservation potential of earth-airtunnel system coupled with non-air-conditioned building. Build Environ 2003;38:807-813.

[18] Al-Ajmi F, Loveday D, Hanby VI. The cooling potential of earth-air heat exchangers for domestic buildings in a desert climate. Build Environ 2006;41:235-244.

51 [19] Ralegaonkar R, Kamath M, Dakwale V. Design and Development of Geothermal Cooling System for 
[20] Mathur A, Srivastava A, Agrawal G, Mathur S, Mathur J. CFD analysis of EATHE system under transient conditions for intermittent operation. Energy Build 2015;87:37-44.

[21] Ahmed SF, Amanullah MTO, Khan MMK, Rasul MG, Hassan NMS. Parametric study on thermal performance of horizontal earth pipe cooling system in summer. Energy Convers Manage 2016;114:324-337.

[22] Gallero FJG, Maestre IR, Gómez PÁ, Blázquez JLF. Numerical and experimental validation of a new hybrid model for vertical ground heat exchangers. Energy Convers Manage 2015;103:511-518.

[23] Kepes Rodrigues M, da Silva Brum R, Vaz J, Oliveira Rocha LA, Domingues dos Santos E, Isoldi LA. Numerical investigation about the improvement of the thermal potential of an Earth-Air Heat Exchanger (EAHE) employing the Constructal Design method. Renew Energy 2015;80:538-551.

[24] Khabbaz M, Benhamou B, Limam K, Hollmuller P, Hamdi H, Bennouna A. Experimental and numerical study of an earth-to-air heat exchanger for air cooling in a residential building in hot semi-arid climate. Energy Build 2016;125:109-121.

[25] Misra R, Bansal V, Agrawal GD, Mathur J, Aseri TK. CFD analysis based parametric study of derating factor for Earth Air Tunnel Heat Exchanger. Appl Energy 2013;103:266-277.

[26] Chel A, G.N.Tiwari. Performance evaluation and life cycle cost analysis of earth to air heat exchanger integrated with adobe building for New Delhi composite climate. Energy Build 2009;41:56-66.

[27] Mihalakakou G, Santamouris M, Asimakopoulos D. Modelling the thermal performance of earth-to-air heat exchangers. Sol Energy 1994;53:301-305.

[28] Bansal V, Misra R, Agrawal GD, Mathur J. Performance evaluation and economic analysis of integrated earth-air-tunnel heat exchanger-evaporative cooling system. Energy Build 2012;55:102-108.

[29] Maerefat M, Haghighi A. Passive cooling of buildings by using integrated earth to air heat exchanger and solar chimney. Renew Energy 2010;35:2316-2324.

[30] Yu Y, Li H, Niu F, Yu D. Investigation of a coupled geothermal cooling system with earth tube and solar chimney. Appl Energy 2014;114:209-217.

[31] Benhammou M, Draoui B, Zerrouki M, Marif Y. Performance analysis of an earth-to-air heat exchanger assisted by a wind tower for passive cooling of buildings in arid and hot climate. Energy Convers Manage 2015;91:1-11.

[32] Rodrigues LT, Gillott M. A novel low-carbon space conditioning system incorporating phase-change materials and earth-air heat exchangers. Intern Journ of Low-Carbon Tech 2013; ctt023.

[33] Jakhar S, Misra R, Bansal V, Soni M. Thermal performance investigation of earth air tunnel heat exchanger coupled with a solar air heating duct for northwestern India. Energy Builds 2015;87:360-369.

[34] Serageldin AA, Abdelrahman AK, Ookawara S. Earth-Air Heat Exchanger thermal performance in Egyptian conditions: Experimental results, mathematical model, and Computational Fluid Dynamics simulation. Energy Convers Manage2016;122:25-38.

[35] Ozgener O, Ozgener L. Determining the optimal design of a closed loop earth to air heat exchanger for greenhouse heating by using exergoeconomics. Energy Build 2011;43:960-965.

[36] Xamán J, Hernández-López I, Alvarado-Juárez R, Hernández-Pérez I, Álvarez G, Chávez Y. Pseudo transient numerical study of an earth-to-air heat exchanger for different climates of México. Energy Build 2015;99:273-283.

[37] Do SL, Baltazar J-C, Haberl J. Potential cooling savings from a ground-coupled return-air duct system for residential buildings in hot and humid climates. Energy Build 2015;103:206-215.

[38] Bisoniya TS, Kumar A, Baredar P. Energy metrics of earth-air heat exchanger system for hot and dry climatic conditions of India. Energy Build 2015;86:214-221.

[39] Abbaspour-Fard MH, Gholami A, Khojastehpour M. Evaluation of an earth-to-air heat exchanger for the north-east of Iran with semi-arid climate. Intern Journ of Green Energy 2011;8:499-510.

[40] M K, J G, C B, B R, F R. WORLD MAP OF THE KÖPPEN-GEIGER CLIMATE CLASSIFICATION updated. Meteorol Z 2006,15:259-263.

[41] Solgi E, Fayaz R, Kari BM. Cooling load reduction in office buildings of hot-arid climate, combining phase change materials and night purge ventilation. Renew Energy 2016;85:725-731.

[42] (IRIMO) IROIMO. Meteorological information of Yazd and Hamadan (Weather Data). In: DATA PROCESSING CENTER; 1951-2005. http://www.irimo.ir/eng/index.php

[43] WeatherBase. Weather Data of Yazd and Hamadan, http://www.weatherbase.com/weather/weather.php3?s=592536\&cityname=Yazd-Iran. http://www.weatherbase.com/weather/weather.php3?s=76704\&cityname=Hamadan-Iran.

[44] Kusuda T, Achenbach PR. Earth temperature and thermal diffusivity at selected stations in the United States. 
In: DTIC Document; 1965

[45] Gan G. Simulation of dynamic interactions of the earth-air heat exchanger with soil and atmosphere for preheating of ventilation air. Appl Energy 2015;158:118-132.

[46] Labs K, Cook j. Passive cooling. Cambridge Massachusetts: MIT Press; 1989.

[47] Ben Jmaa Derbel H, Kanoun O. Investigation of the ground thermal potential in tunisia focused towards heating and cooling applications. Appl Therm Engin 2010;30:1091-1100.

[48] Ghiabaklou Z. Fundamentals of building physics: Passive Cooling. Tehran: Amirkabir University; 2012.

[49] Elmer D, Schiller G. A preliminary examination of the dehumidification potential of earth/air heat exchangers. In: Proceedings of the 1st national passive cool confer, Miami 1981; pp. 161-165.

[50] Maerefat M, Haghighi AP. Passive cooling of buildings by using integrated earth to air heat exchanger and solar chimney. Renew Energy 2010;35:2316-2324.

[51] Belatrache D, Bentouba S, Bourouis M. Numerical analysis of earth air heat exchangers at operating conditions in arid climates. Intern Journ of Hydrogen Energy 2016.

[52] Barakat S, Ramzy A, Hamed AM, El Emam SH. Enhancement of gas turbine power output using earth to air heat exchanger (EAHE) cooling system. Energy Convers Manage 2016;111:137-146.

[53] Badescu V, Isvoranu D. Pneumatic and thermal design procedure and analysis of earth-to-air heat exchangers of registry type. Appl Energy 2011;88:1266-1280.

[54] Dhaliwal AS, Goswami D, Das G. Heat transfer analysis in environmental control using an underground air tunnel. Journ Sol Energy Engin 1985;107:141-145.

[55] Bansal V, Mishra R, Agarwal GD, Mathur J. Performance analysis of integrated earth-air-tunnel-evaporative cooling system in hot and dry climate. Energy Build 2012;47:525-532.

[56] Daneshvar M, Bagherzadeh A, Tavousi T. Assessment of bioclimatic comfort conditions based on Physiologically Equivalent Temperature (PET) using the RayMan Model in Iran. Open Geosciences 2013;5:53-60. 